\title{
PENGARUH NILAI RELIGIUSITAS TERHADAP HASIL BELAJAR SISWA DALAM PEMBELAJARAN PENDIDIKAN AGAMA ISLAM DI SDN 10 LUBUK ALUNG
}

\author{
Rahmi Mulya ${ }^{1}$, Sulaiman ${ }^{2}$ \\ 1,2Jurusan Ilmu Agama Islam Universitas Negeri Padang, Indonesia \\ Email kontributor: rahmimulya706@gmail.com
}

\begin{abstract}
Abstrak
Penelitian ini bertujuan untuk mengetahui pengaruh nilai-nilai religiusitas terhadap hasil belajar siswa dalam pembelajaran Pendidikan Agama Islam kelas IV dan V di SDN 10 Lubuk Alung. Jenis penelitian ini adalah penelitian kuantitatif dengan menggunakan metode penelitian asosiatif. Populasi dalam penelitian ini yaitu kelas IV dan V di SDN 10 Lubuk Alung. Sampel dalam penelitian ini diambil dari seluruh populasi yang berjumlah 31 responden. Teknik pengumpulan data menggunakan angket (kuesioner) dan dokumentasi. Analisis data menggunakan analisis regresi linear sederhana, dengan nilai-nilai religiusitas sebagai variabel bebas dan hasil belajar siswa sebagai variabel terikat. Hasil penelitian menunjukkan bahwa nilai-nilai religiusitas secara parsial berpengaruh positif dan signifikan terhadap hasil belajar siswa dalam pembelajaran Pendidikan Agama Islam.
\end{abstract}

Kata kunci: Nilai Religiusitas, Hasil Belajar, Pendidikan Agama Islam

\begin{abstract}
This study aims to determine the effect of religious values on student learning outcomes in Islamic Religious Education class IV and V at SDN 10 Lubuk Alung. This type of research is quantitative research using associative research methods. The population in this study were grades IV and V at SDN 10 Lubuk Alung. The sample in this study was taken from the entire population of 31 respondents. The data collection technique using a questionnaire (kuesioner) and documentation. Data analysis used simple linear regression analysis, with religiosity values as the independent variable and student learning outcomes as the dependent variable. The results of the study indicate that the values of religiosity partially have a positive and significant effect on student learning outcomes in learning Islamic Religious Education.
\end{abstract}

Keywords: The Value Of Religiosity, Learning Outcomes, Islamic Religious Education 


\section{A. PENDAhULUAN}

Pendidikan merupakan suatu kebutuhan yang sangat penting bagi kehidupan dan sebagai jembatan dalam meningkatkan kualitas sumber daya manusia, untuk itu pendidikan yang bermutu tinggi diharapkan menghasilkan manusia yang berkualitas. Tujuan dari Pendidikan Nasional yaitu untuk mengembangkan potensi diri peserta didik agar menjadi manusia yang beriman dan bertaqwa kepada Tuhan Yang Maha Esa, memiliki pengetahuan dan keterampilan, berbudi pekerti yang luhur, sehat jasmani dan rohani, berkepribadian yang mantap, cerdas, kreatif, mandiri dan memiliki rasa tanggung jawab (Depdiknas, 2003).

Pendidikan bertujuan untuk mengembangkan potensi yang ada dalam diri siswa agar memiliki kekuatan jiwa keagamaan sesuai yang dilakukan dalam Pendidikan Agama Islam. Pendidikan Agama Islam merupakan pendidikan yang dilaksanakan berdasarkan ajaran Islam. Pembelajaran pendidikan Agama Islam tujuan akhirnya adalah pemahaman, penghayatan dan pengamalan ajaran Islam secara menyeluruh sebagai sesuatu yang telah diyakini oleh peserta didik dan akan membangun landasan bagi sebuah pandangan hidupnya demi keselamatan dan kesejahteraan hidup di dunia maupun di akhirat (Daradjat, 2014: 86).

Pendidikan Agama Islam adalah usaha yang berupa pengajaran, bimbingan dan asuhan terhadap anak didik agar kelak setelah selesai pendidikannya dapat memahami, menghayati, dan mengamalkan agama Islam, serta menjadikannya sebagai jalan kehidupan atau pandang hidup (way of life), baik pribadi maupun kehidupan bermasyarakat (Muliawan, 2005: 86). Dasar Pendidikan Islam adalah Alquran dan sunnah nabi Muhammad Saw yang dapat dikembangkan melalui ijtihad, al-maslahah al-mursalah, istihsan, qiyas, dan sebagainya. Dasar yang menjadi acuan Pendidikan Islam merupakan sumber nilai kebenaran dan kekuatan yang dapat menghantarkan pada aktivitas yang dicita-citakan. Nilai yang terkandung di dalamnya menjadi penting untuk diperhatikan hal-hal yang dapat mencerminkan nilai universal yang dapat dikonsumsikan oleh seluruh umat manusia. Sedangkan tujuan dari Pendidikan Agama Islam bukan hanya semata-mata untuk memenuhi kebutuhan intelektual saja, melainkan segi penghayatan juga pengamalan serta pengaplikasiannya dalam kehidupan dan sekaligus menjadi pegangan hidup bagi seluruh umat manusia (Hawi, 2014). Pendidikan dalam Islam adalah bukan sekedar pengajaran, karena pendidikan lebih dari itu, yaitu di samping proses transfer ilmu, juga merupakan proses alih nilai, dan pembentukan kepribadian dengan segala aspek yang dicakupnya (Alfadhil, 2019).

Adapun ruang lingkup Pendidikan Agama Islam meliputi aspek ketuhanan, kemanusiaan dan kealam semestaan serta didasari dengan aqidah (keyakinan), syariah (hukum) dan akhlak atau perilaku (Umar \& Ismail, 2020). Jadi Pendidikan Agama Islam merupakan mata pelajaran yang sangat penting diwajibkan ada pada kurikulum pendidikan di Indonesia. Dalam mata pelajaran Pendidikan Agama Islam mencakup yaitu: Alquran hadis, Fikih, Akidah, Akhlak, Sejarah Kebudayaan Islam dan Bahasa Arab. Penjelasan Pendidikan Agama Islam sebagai sumber nilai atau pedoman, ternyata belum mewarnai lingkungan dan atmosfer kehidupan sekolah pada umumnya. Faktanya perubahan tata nilai kehidupan masyarakat telah membawa dampak yang penting. Salah satu bentuk perubahan tersebut adalah lemahnya keyakinan keagamaan atau religiusitas masyarakat. Keadaaan ini berlawanan dengan ajaran Islam sekaligus tidak mendukung pencapaian tujuan pendidikan nasional. Hingga saat ini pelaksanaan 
pendidikan agama yang berlangsung di sekolah masih dianggap kurang berhasil dalam menggarap sikap dan perilaku keberagamaan atau religiusitas peserta didik serta membangun moral dan etika bangsa (Hidayati, 2016).

Religiusitas itu sendiri merupakan internalisasi nilai-nilai agama dalam diri seseorang. Internalisasi di sini berkaitan dengan kepercayaan terhadap ajaran-ajaran agama baik dalam hati maupun dalam ucapan. Kepercayaan ini kemudian diaktualisasikan dalam perbuatan dan tingkah laku sehari-hari (Evi \& Farid, 2014). Adapun menurut Yaumi dalam (Mahmudi \& Attamimi, 2020) Religiusitas merupakan sikap dan perilaku patuh terhadap ajaran yang dianutnya, toleran dengan agama lain dan hidup rukun dengan pemeluk agama lain. Sisi religiusitas seseorang itu tercermin pada sikap, perilaku, cara berpikir, tutur kata, dan penampilannya yang sesuai dengan aturan-aturan dan norma agama (Mustari, 2014:1). Berdasarkan dari kedua pendapat di atas, maka hal tersebut sejalan dengan yang dikemukakan Umro (2018:153) bahwa religiusitas merupakan penghayatan dan pelaksanaan ajaran agama dalam kehidupan sehari-hari.

Nilai menurut Steeman dalam (Jakaria Umro, 2018) adalah sesuatu yang dijunjung tinggi, yang mewarnai dan menjiwai tindakan seseorang. Kemudian Rokech dan Bank dalam (Asmaun Sahlan, 2010) menyatakan nilai merupakan suatu tipe kepercayaan yang berada pada suatu lingkup sistem kepercayaan dimana seseorang bertindak atau menghindari suatu tindakan mengenai sesuatu yang dianggap pantas atau tidak pantas. Berarti ini suatu pemaknaan atau pemberian arti terhadap suatu objek. Sedangkan keberagamaan merupakan suatu sikap atau kesadaran yang muncul didasarkan atas keyakinan atau kepercayaan seseorang terhadap suatu agama. Jadi nilai disini menjadi pengarah, pengendali dan penentu perilaku seseorang dalam melakukan suatu tindakan atau perbuatan. Adapun Nilai religius adalah nilai yang bersumber dari keyakinan keTuhanan yang ada pada diri seseorang (Sjarkawi, 2008). Dengan demikian nilai religius ialah sesuatu yang berguna dan dilakukan oleh manusia, berupa sikap dan perilaku yang patuh dalam melaksanakan ajaran agama yang dianutnya.

Kemudian nilai religius yang dijelaskan Wati \& Arif (2017) merupakan salah satu nilai karakter yang dijadikan sebagai sikap dan perilaku yang patuh dalam melaksanakan ajaran agama yang dianut, toleran terhadap pelaksanaan ibadah agama lain, dan hidup rukun dengan pemeluk agama lain. Karakter religius perlu di ajarkan sejak anak usia dini, beberapa karakter religius yang harus ditanakam kepada anak yaitu nilai norma dan moral seperti jujur, disiplin, mandiri, kerja keras, kreatif, hormat kepada orang lain, tanggung jawab, cinta tanah air, kepemimpinan dan keadilan. Salah satu tempat untuk menanamkan karakter religius pada anak adalah sekolah. Uno (2008) menjelaskan bahwa karakteristik siswa merupakan salah satu hal yang perlu diidentifikasi oleh guru untuk digunakan sebagai petunjuk dalam upaya mengoptimalkan proses pembelajaran, diantaranya adalah religiusitas tinggi atau rendah yang memiliki kontribusi besar dalam pembentukan karakter dan hasil belajar siswa dalam mengimplementasikan nilai-nilai keIslaman dalam kehidupan sehari-hari.

Fathurrohman (2015) menjelaskan bahwa nilai religiusitas terbagi menjadi lima macam; 1) Nilai ibadah, yaitu penghambaan terhadap Allah SWT tercantum dalam dua kalimat syahadat "asyhadu alla ilaaha illallaah, waasyhadu anna M uhammadar Rasulullah". Mengabdikan atau menghambakan diri kepada Allah SWT merupakan inti dari ajaran Islam. Dalam Islam terdapat dua bentuk nilai ibadah yakni; pertama, ibadah mahdhah (hubungan manusia langsung dengan 
Allah SWT). kedua, ibadah ghairu mahdhah yang berkaitan dengan manusia lain. Semua itu bermuara pada tujuan mencari ridho Allah SWT. Suatu nilai ibadah terletak pada dua hal yaitu sikap batin (yang mengakui dirinya sebagai hamba Allah SWT) dan perwujudannya dalam bentuk ucapan dan tindakan. 2) Nilai Jihad (Ruhul Jihad), artinya jiwa yang mendorong manusia untuk bekerja dan berjuang dengan sungguh-sungguh. Ruhul jihad didasari dengan tujuan hidup manusia yaitu hablum minallah (hubungan manusia dengan Allah SWT), hablumminannas (hubungan manusia dengan manusia), hablum min al-alam (hubungan manusia dengan alam). Jihad di dalam Islam merupakan prioritas utama dalam beribadah kepada Allah SWT. Mencari ilmu merupakan salah satu manifestasi dari sifat Jihadun nafsi (berjuang melawan hawa nafsu) yaitu memerangi kebodohan dan kemalasan. 3) Nilai akhlak dan kedisiplinan, akhlak adalah perilaku dan cerminan keadaan jiwa yang ada pada diri manusia. Apabila akhlaknya baik maka jiwanya akan baik, begitupun sebaliknya. Sedangkan kedisiplinan itu termanifestasi dalam kebisaaan manusia ketika melaksanakan ibadah rutin setiap hari. Apabila manusia melaksanakan ibadahnya dengan tepat waktu, maka secara otomatis nilai kedisiplinan telah tertanam pada diri orang tersebut. Pada lembaga sekolah nilai akhlak dan kedisiplinan harus diperhatikan dan menjadi sebuah budaya religius sekolah. 4) Nilai Keteladanan, merupakan hal yang penting dalam pendidikan dan pembelajaran, terutama dari guru sebagai seorang yang patut dicontoh oleh siswa. Jika guru mempunyai sikap yang baik dan mampu menunjukkan perilaku akhlaq alkarimah maka guru akan menjadi seorang figur sentral bagi siswanya dalam segala hal. Sekolah memiliki ciri khas keagamaan, maka nilai keteladanan harus diutamakan. Mulai dari cara berpakaian, perilaku, ucapan dan sebagainya. 5) Nilai amanah dan ikhlas dalam konteks pendidikan, nilai amanah harus dipegang oleh seluruh pengelola lembaga pendidikan, baik itu kepala sekolah, guru, staf, maupun komite di lembaga tersebut. Jika nilai amanah dapat ditanamkan dengan baik kepada siswa, maka akan membentuk karakter siswa yang jujur dan dapat dipercaya. Begitupun dengan nilai ikhlas yang juga sangat penting untuk ditanamkan kepada diri siswa. Ikhlas berarti tidak adanya rasa pamrih atas segala sesuatu yang telah diperbuat. Dengan bersikap ikhlas maka setiap amalan yang diperbuat semata-mata hanya mengharapkan ridho Allah SWT.

Adapun faktor yang mempengaruhi sikap religiusitas seseorang, menurut Najib (2018) ada dua; pertama faktor internal kejiwaan manusia yaitu kepatuhan dan ketaatan kepada Allah SWT. Kedua faktor eksternal, yaitu segala faktor yanag dapat mempengaruhi sikap religiusitas seseorang seperti cerita Nabi dan Rasul yang dapat menjadi teladan, berbagai ritual yang dijalankan oleh masyarakat, pengaruh teknologi dan lain sebagainya. Dalam hal ini, Metode keteladanan dan pembiasaan yang dilakukan oleh guru pendidikan agama islam sangat berpengaruh terhadap kejiwaan siswa. Jika nilai religius sudah tertanam dalam diri siswa dan di pupuk dengan baik maka dengan sendirinya akan tumbuh menjadi pribadi yang baik (Syarnubi, 2019).

Khoerunnisa (2017) menyebutkan kaitan nilai-nilai religiusitas dengan hasil belajar yaitu suatu hasil atau tujuan yang ingin dicapai oleh tiap sekolah agar siswa dapat memperoleh prestasi yang baik. Cara memperoleh hasil belajar yang baik diperlukan motivasi yang baik juga, motivasi tidak terlepas dari dua faktor penting yaitu, faktor internal maupun eksternal yang berpengaruh bagi hasil belajar. Ahmad (2013) menyebutkan secara sederhana, yang dimaksud 
dengan hasil belajar siswa adalah kemampuan yang diperoleh anak setelah melalui kegiatan belajar. Hasil belajar menurut Agus (2010) adalah perubahan perilaku secara keseluruhan bukan hanya salah satu aspek potensi kemanusiaan saja. Artinya, hasil pembelajaran yang dikategorisasi oleh para pakar pendidikan sebagaimana tersebut diatas tidak dilihat secara fregmentaris atau terpisah, melainkan komprehensif. Adapun menurut Saputra, dkk (2018) hasil belajar merupakan salah satu acuan terhadap keberhasilan dalam proses pendidikan.

Sejalan dengan yang telah di kemukakan di atas Nasution (2017) menyatakan bahwa hasil belajar siswa merupakan salah satu tujuan dari proses pembelajaran di sekolah, untuk itu seorang guru perlu mengetahui, mempelajari beberapa metode mengajar, serta dipraktikkan pada saat megajar. Supaya menghasilkan prestasi atau hasil belajar siswa yang tinggi, maka guru dituntut untuk mendidik dan mengajar siswa dengan menggunakan metode pembelajaran yang dibutuhkan dalam proses pembelajaran di kelas. Pembelajaran menurut Sumantri (2016) merupakan suatu sistem yang terdiri dari berbagai komponen yang saling berhubungan satu dengan yang lain. Komponen tersebut meliputi tujuan, materi, metode, dan evaluasi. Keempat komponen pembelajaran tersebut harus diperhatikan oleh guru dalam memilih dan menentukan media, metode, strategi dan pendekatan apa yang akan digunakan dalam kegiatan pembelajaran. Jadi, pembelajaran adalah proses interaksi antara guru dan siswa dalam bentuk bantuan yang diberikan guru agar terjadi proses perolehan ilmu pengetahuan.

Menurut Nana Sudjana (2011: 25) Bentuk hasil belajar dalam Benyamin Bloom secara garis besar membaginya menjadi 3 ranah, yaitu; 1) Ranah Kognitif yang mencakup kegiatan mental (otak) meliputi; (a) Pengetahuan (knowledge), yaitu mengingat akan hal-hal yang pernah dipelajari dan disimpan dalam ingatan. (b) Pemahaman (comprehension), yaitu kemampuan untuk mengerti atau memahami sesuatu setelah diketahui. (c) Penerapan (application), yaitu kesanggupan seseorang untuk menerapkan atau menggunakan ide-ide umum, metode, prinsip dan lain sebagainya dalam situasi baru dan konkret. (d) Analisis (analysis), yaitu kemampuan merinci atau menguraikan materi kedalam komponen-komponen, sehingga dapat dipahami dengan baik. (e) Sintesis (synthesis), yaitu kemampuan memadukan konsep atau komponenekomponen sehingga membentuk suatu pola struktur atau bentuk baru. (f) Evaluasi (evaluation), yaitu kemampuan untuk berpikir dan memberikan penilaian serta pertimbangan dari nilai-nilai materi, tujuannya untuk membentuk suatu pendapat mengenai suatu hal dengan mempertanggungjawabkan pendapat tersebut. Evaluasi adalah jejang berpikir yang paling tinggi dalam ranah kognitif. 2) Ranah afektif, berkaitan dengan perkembangan sikap, minat, perasaan, nilai-nilai atau disebut juga dengan perkembangan emosional dan moral, meliputi; Penerimaan (receiving), Sambutan atau partisipasi (responding), penilaian (valuing), organisasi (organization), karakterisasi (characterization). 3) Ranah psikomotorik, berhubungan dengan perkembangan keterampilan (skill) yang mengandung unsur motorik dan kemampuan fisik seseorang, meliputi; persepsi, kesiapan, gerakan terbimbing, gerakan yang terbiasa, gerakan kompleks, penyesuaian pola gerakan atau adaptasi, dan kreativitas atau penciptaan.

Kemudian faktor yang mempengaruhi hasil belajar terdiri dari dua faktor yaitu internal dan eksternal sebagaimana yang diungkapkan oleh Abu Ahmadi dalam (Fatmawati, 2018) berikut ini; 1) faktor internal, meliputi; (a) Faktor jasmaniah (fisiologi) baik yang bersifat bawaan maupun yang diperoleh. Misalnya penglihatan, pendengaran, struktur tubuh dan 
sebagainya. (b) Faktor psikologis baik yang bersifat bawaan maupun yang diperoleh, terdiri atas: faktor intelektif yang meliputi: a. Faktor potensial yaitu kecerdasan dan bakat. b. Faktor kecakapan nyata yaitu prestasi yang dimiliki. Faktor non-intelektif, yaitu unsur-unsur kepribadian tertentu seperti sikap, kebisaaan, motivasi, perilaku, kebutuhan, minat, emosi, penyesuaian diri, faktor kematangan fisik maupun psikis. 2) Faktor eksternal, meliputi; (a) Faktor sosial yang terdiri dari: lingkungan keluarga, lingkungan sekolah, dan lingkungan masyarakat. (b) Faktor budaya, seperti adat istiadat, ilmu pengetahuan, teknologi, kesenian. (c) Faktor lingkungan spiritual atau keamanan faktor-faktor yang saling berinteraksi secara langsung ataupun tidak langsung dapat mencapai prestasi belajar.

Setiap proses pendidikan akan menghasilkan hasil belajar. Hasil belajar dalam lingkungan sekolah dapat dilihat dari prestasi belajar. Prestasi belajar sendiri merupakan kemampuan, kecakapan dan keterampilan serta sikap yang dimiliki siswa, berupa angka-angka dari hasil pengukuran dengan tes. Adapun maksud dari prestasi belajar disini adalah hasil belajar siswa yang berupa angka-angka yang tercantum dalam buku rapor (Khaeriyah, 2019:4).

Berdasarkan hasil observasi dan wawancara penulis dengan Bapak Eljon, S.Pd selaku kepala sekolah di SDN 10 Lubuk Alung yang terletak di Jl. Balah Hilie, Kec. Lubuk Alung, Kab. Padang Pariaman. Menyatakan bahwa dari keseluruhan kelas yang ada di SDN 10 Lubuk Alung, siswa kelas IV dan V dinyatakan memiliki nilai rata-rata hasil belajar yang tergolong rendah. Hal ini dapat dilihat dari data siswa SDN 10 Lubuk Alung yang masih banyak memperoleh nilai cukup (65) bahkan sebagian lainnya dibawah KKM (55 dan 60) pada ujian akhir semester ganjil. Kondisi di atas diperkuat dengan pendapat yang diungkapkan oleh guru Pendidikan Agama Islam yaitu Nofridaleli dan wali kelas masing-masing kelas tersebut yaitu Delfianis dan Mesi Anisa yang menyatakan bahwa dalam kegiatan belajar mengajar siswa sering malas mengerjakan tugas yang diberikan guru, tidak bersemangat atau kurangnya motivasi dalam diri siswa untuk belajar, siswa tidak sopan dalam berbicara atau berinteraksi baik dengan guru maupun dengan temannya, siswa tidak hormat kepada guru sebagai wujud dari karakter religius terhadap orang lain, dan kurangnya kesadaran siswa dalam mengerjakan sholat baik di sekolah maupun di rumah, kurangnya rasa toleransi siswa bahkan ada juga siswa yang berkelahi di sekolah.

Sehubungan dengan permasalahan di atas maka peneliti tertarik untuk mengkaji hasil penelitian dengan judul penelitian "Pengaruh Nilai-nilai Religiusitas Terhadap Hasil Belajar Siswa Dalam Pembelajaran Pendidikan Agama Islam Di SDN 10 Lubuk Alung”.

\section{B. METODE PENELITIAN}

Metode pada penelitian ini menggunakan pendekatan kuantitatif yaitu data yang diukur dengan menggunakan statistika dalam penyajiannya (Kountur, 2003:16). Pendekatan kuantitatif dalam penelitian ini bertujuan untuk mengetahui pengaruh nilai-nilai religiusitas terhadap hasil belajar siswa dalam pembelajaran Pendidikan Agama Islam kelas IV dan V di SDN 10 Lubuk Alung. Jenis penelitian ini adalah penelitian kuantitatif dengan menggunakan metode penelitian asosiatif. Penelitian asosiatif adalah penelitian yang bertujuan untuk mengetahui hubungan kausalitas atau sebab-akibat antara dua variabel atau lebih dan variabel lainnya dengan suatu pengujian melalui suatu perhitungan statistik didapatkan hasil pembuktian yang menunjukkan hipotesis di tolak atau diterima Sugiyono (2010). Variabel adalah suatu atribut, sifat, nilai dari 
orang, obyek atau kegiatan yang mempunyai variasi tertentu yang ditetapkan oleh penelitian untuk dipelajari dan ditarik kesimpulannya (Sugiyono, 2012). Penelitian asosiatif bertujuan untuk mengetahui pengaruh antara dua variabel atau lebih yaitu nilai-nilai religiusitas dan hasil belajar siswa dalam pembelajaran Pendidikan Agama Islam kelas IV dan V di SDN 10 Lubuk Alung.

Populasi pada penelitian ini yaitu kelas IV dan V di SDN 10 Lubuk Alung, jika digabungkan berjumlah 31 siswa. Kemudian sampel diambil dari seluruh populasi sebanyak 31 responden. Teknik pengumpulan data dalam penelitian ini melalui angket dan dokumentasi. Angket yang digunakan bersifat tertutup atau terstruktur, dimana responden tinggal memilih alternatif jawaban yang telah disediakan. Instrumen angket dalam penelitian ini terdiri dari 30 butir pernyataan yang akan diuji cobakan kepada 28 siswa, kemudian hasil uji coba angket tersebut dianalisis validitasnya menggunakan rumus product moment atau dikenal juga dengan pearson korelasi. Berdasarkan hasil analisis diperoleh 19 butir pernyataan yang valid dan 11 butir pernyataan yang tidak valid.

Uji reliabilitas instrumen untuk mengetahui kesesuaian instrumen dalam mengumpulkan data penelitian. Suatu instrumen dikatakan reliabel apabila instrumen tersebut dipakai untuk mengukur suatu gejala yang sama dalam waktu yang berbeda akan menghasilkan data yang sama. Untuk menguji reliabilitas digunakan rumus alpha, rumus ini digunakan karena angket atau kuisioner yang dipergunakan dalam penelitian ini tidak terdapat jawaban yang bernilai salah atau nol. Kriteria uji reliabilitas jika rhitung > rtabel pada taraf signifikan 5\% berarti instrumen reliable, sebaliknya jika rhitung < rtabel maka instrumen tidak reliabel.

\section{Tabel 1. Uji Reliabilitas Angket Nilai-nilai Religiusitas Siswa}

\begin{tabular}{|r|r|}
\hline \multicolumn{2}{|c|}{ Reliability Statistics } \\
\hline & \\
\hline Cronbach's Alpha & N of Items \\
\hline .782 & 30 \\
\hline
\end{tabular}

Dari tabel uji reliabilitas di atas diperoleh hasil r-hitung 0.782. Sedangkan nilai r-tabel pada taraf signifikan 5\% adalah 0.374 dengan jumlah responden 28. Maka r-hitung 0.782> rtabel 0.374 dan tergolong kategori koefisien di nilai antara 0,60-0,80 sehingga dapat disimpulkan bahwa instrumen dinyatakan reliabel dan memiliki tingkat reliabilitas yang tinggi.

\section{HASIL DAN PEMBAHASAN}

\section{Analisis Data}

Data mengenai nilai-nilai religiusitas yang berhasil dikumpulkan dari responden sebanyak 31 siswa, secara kuantitatif menunjukkan bahwa skor tertinggi adalah 76 dan skor terendah 53. Tingkat nilai-nilai religiusitas diukur dengan pengukuran yang sudah ditentukanhasil perhitungan diperoleh kategori nilai-nilai religiusitas siswa kelas IV dan V dapat dilihat pada tabel berikut ini: 
Tabel 2. Distribusi Kategori Nilai-nilai Religiusitas siswa

\begin{tabular}{cccc}
\hline Kategori Nilai-nilai Religiusitas & $\mathbf{i = 8}$ & $\mathbf{F}$ & $\mathbf{\%}$ \\
\hline Rendah & $53-60$ & 5 & 16,1 \\
\hline Sedang & $61-68$ & 22 & 71,0 \\
\hline Tinggi & $69-76$ & 4 & 12,9 \\
\hline & Total & $\mathbf{3 1}$ & $\mathbf{1 0 0 , 0}$ \\
\hline
\end{tabular}

Berdasarkan data tabel distribusi di atas, dapat dilihat nilai-nilai religiusitas siswa kelas IV dan V SDN 10 Lubuk Alung berada dalam kategori kurang baik/rendah sebanyak 5 siswa atau $16,1 \%$ pada interval 53-60, kategori cukup baik/sedang sebanyak 22 siswa atau 71,0\% terdapat pada interval 61-68, kategori sangat baik/tinggi sebanyak 4 siswa atau 12,9\% terdapat pada interval 69-76. Dari data hasil analisis tersebut dapat diketahui bahwa sebagian besar nilainilai religiusitas siswa kelas IV dan V SDN 10 Lubuk Alung berada pada kategori cukup baik/sedang.

Data mengenai hasil belajar siswa dalam pembelajaran Pendidikan Agama Islam yang berhasil dikumpulkan dari responden sebanyak 31 siswa, secara kuantitatif menunjukkan bahwa skor tertinggi adalah 88 dan skor terendah 49. Tingkat nilai hasil belajar siswa diukur dengan pengukuran yang sudah ditentukan hasil perhitungan diperoleh kategori hasil belajar siswa dalam pembelajaran Pendidikan Agama Islam kelas IV dan V dapat dilihat pada tabel berikut ini:

Tabel 3. Distribusi Kategori Nilai-nilai Religiusitas siswa

\begin{tabular}{cccc}
\hline Kategori Hasil Belajar & $\mathbf{i = 1 3}$ & $\mathbf{F}$ & $\mathbf{\%}$ \\
\hline Rendah & $49-61$ & 7 & 22,6 \\
\hline Sedang & $62-74$ & 19 & 61,3 \\
\hline Tinggi & $75-88$ & 5 & 16,1 \\
\hline & Total & $\mathbf{3 1}$ & $\mathbf{1 0 0 , 0}$ \\
\hline
\end{tabular}

Berdasarkan data tabel distribusi di atas, dapat dilihat hasil belajar siswa dalam pembelajaran Pendidikan Agama Islam kelas IV dan V SDN 10 Lubuk Alung berada dalam kategori rendah sebanyak 7 siswa atau $22.6 \%$ pada interval 49-61, kategori sedang sebanyak 19 siswa atau $61.3 \%$ terdapat pada interval 62-74, kategori tinggi sebanyak 5 siswa atau $16.1 \%$ terdapat pada interval 75-88. Dari data hasil analisis tersebut dapat diketahui bahwa sebagian besar hasil belajar siswa dalam pembelajaran Pendidikan Agama Islam kelas IV dan V SDN 10 Lubuk Alung berada pada kategori sedang.

\section{Uji Normalitas}

Uji normalitas merupakan bagian dari uji asumsi klasik. Uji normalitas dilakukan dengan uji Kolmogorov-Smirnov. Hasil analisis menunjukkan bahwa nilai signifikansi Kolmogorov- 
Smirnov (Asymp. Sig) yaitu 0.200>0,05. Sehingga dapat disimpulkan bahwa nilai residual berdistribusi normal. Berikut adalah tabel hasil uji normalitas:

Tabel 4. Hasil Uji Normalitas

\begin{tabular}{l|l|l}
\hline \multicolumn{2}{l}{ One-Sample Kolmogorov-Smirnov Test } \\
\hline \multicolumn{2}{|l}{} & \multicolumn{1}{c}{ Unstandardized Residual } \\
\hline $\mathrm{N}$ & Mean & 31 \\
\cline { 2 - 3 } Normal Parameters ${ }^{\mathrm{a}, \mathrm{b}}$ & Std. Deviation & 9.20583970 \\
\hline Most Extreme Differences & Absolute & .107 \\
\cline { 2 - 3 } & Positive & .107 \\
\cline { 2 - 3 } & Negative & -.106 \\
\hline Test Statistic & .107 \\
\hline Asymp. Sig. (2-tailed) & $.200^{\mathrm{c}, \mathrm{d}}$ \\
\hline a. Test distribution is Normal. & \\
\hline b. Calculated from data. \\
\hline c. Lilliefors Significance Correction. \\
\hline d. This is a lower bound of the true significance. \\
\hline
\end{tabular}

\section{Hasil Uji Hipotesis}

a. Analisis Regresi Linear Sederhana

Analisis regresi linear sederhana digunakan untuk menguji hipotesis tentang pengaruh secara parsial variabel bebas $(\mathrm{X})$ yaitu nilai-nilai religiusitas terhadap variabel terikat $(\mathrm{Y})$ yaitu hasil belajar siswa dalam pembelajaran Pendidikan Agama Islam kelas IV dan V di SDN 10 Lubuk Alung. Hasil analisis regresi linear sederhana dapat dilihat pada tabel output berikut ini:

Tabel 5. Hasil Uji Analisis Regresi Linear Sederhana

Coefficients $^{\mathrm{a}}$

\begin{tabular}{|c|c|c|c|c|c|c|}
\hline & & \multicolumn{2}{|c|}{$\begin{array}{l}\text { Unstandardized } \\
\text { Coefficients }\end{array}$} & $\begin{array}{l}\text { Standardized } \\
\text { Coefficients }\end{array}$ & \multirow[b]{2}{*}{$\mathrm{t}$} & \multirow[b]{2}{*}{ Sig. } \\
\hline \multicolumn{2}{|c|}{ Model } & B & Std. Error & Beta & & \\
\hline 1 & (Constant) & -2.353 & .415 & & -5.664 & .000 \\
\hline & $X$ & .061 & .006 & .888 & 10.409 & .000 \\
\hline
\end{tabular}

a. Dependent Variable: Y

Dari ouput diatas dapat diketahui persamaaan regresi linear sederhana sebagai berikut; $\mathrm{Y}=-2,353+0,061 \mathrm{X}$ 
Dari persamaan di atas, dapat di simpulkan bahwa ada pengaruh antara nilai-nilai religiusitas dan hasil belajar siswa dalam pembelajaran Pendidikan Agama Islam. Koefisien regresi variabel nilai nilai religiusitas yang berjumlah 0,061 , dapat diartikan bahwa setiap penambahan $1 \%$ nilai-nilai religiusitas (X) akan meningkatkan hasil belajar siswa dalam pembelajaran pendidikan Agama Islam kelas IV dan V di SDN 10 Lubuk Alung sebesar 0,061\%.

b. Hasil Uji Koefisien Determinasi $\left(\mathrm{R}^{2}\right)$

Berikut ini nilai koefisien Determinasi $\left(\mathrm{R}^{2}\right)$ yang dihasilkan pada model regresi dalam penelitian ini:

Tabel 6. Hasil Uji Koefisien Determinasi $\left(\mathbf{R}^{2}\right)$

\begin{tabular}{|c|c|c|c|c|}
\hline \multicolumn{5}{|c|}{ Model Summary } \\
\hline Model & $\mathrm{R}$ & R Square & $\begin{array}{ll}\text { Adjusted } & \mathrm{R} \\
\text { Square } & \end{array}$ & $\begin{array}{l}\text { Std. Error of } \\
\text { the Estimate }\end{array}$ \\
\hline 1 & $.888^{\mathrm{a}}$ & .789 & .782 & .294 \\
\hline
\end{tabular}

a. Predictors: (Constant), $\mathrm{X}$

Berdasarkan output pada tabel di atas, diketahui $\mathrm{R}$ sebesar 0,888 dan nilai $\mathrm{R}$ Square sebesar 0,789. Hal ini mengandung arti bahwa persentase pengaruh nilai-nilai religiusitas (X) terhadap hasil belajar siswa dalam pembelajaran pendidikan Agama Islam kelas IV dan V di SDN 10 Lubuk Alung (Y) secara simultan adalah 78,9\%, sedangkan 21,1\% dipengaruhi oleh faktor lain.

\section{c. Hasil Uji T}

Uji T digunakan untuk menentukan signifikan konstanta dari variabel $(\mathrm{X})$ yaitu nilai-nilai religiusitas terhadap variabel (Y) yaitu hasil belajar siswa dalam pembelajaran pendidikan Agama Islam.

Tabel 7. Hasil Uji T (Parsial)

\section{Coefficients $^{\mathrm{a}}$}

\begin{tabular}{|c|c|c|c|c|c|c|}
\hline \multirow{2}{*}{\multicolumn{2}{|c|}{ Model }} & \multicolumn{2}{|c|}{$\begin{array}{l}\text { Unstandardized } \\
\text { Coefficients }\end{array}$} & \multirow{2}{*}{$\begin{array}{l}\text { Standardized } \\
\text { Coefficients } \\
\text { Beta }\end{array}$} & \multirow[b]{2}{*}{$\mathrm{T}$} & \multirow[b]{2}{*}{ Sig. } \\
\hline & & B & Std. Error & & & \\
\hline \multirow[t]{2}{*}{1} & (Constant) & -2.353 & .415 & & -5.664 & .000 \\
\hline & $X$ & .061 & .006 & .888 & 10.409 & .000 \\
\hline
\end{tabular}

a. Dependent Variable: Y

Hasil pengujian hipotesis diperoleh nilai t-hitung sebesar 10,409 > 1,695 dan nilai sig dari nilai-nilai religiusitas sebesar 0,000 yang mana $0,000<0,05$, sehingga $\mathrm{H} 0$ ditolak dan $\mathrm{Ha}$ diterima, artinya nilai-nilai religiusitas secara parsial berpengaruh positif dan signifikan terhadap hasil belajar siswa dalam pembelajaran pendidikan Agama Islam kelas IV dan V di SDN 10 
Lubuk Alung. Semakin tinggi nilai-nilai religiustitas siswa maka semakin tinggi pulahasil belajar siswa dalam pembelajaran pendidikan Agama Islam kelas IV dan V di SDN 10 Lubuk Alung.

\section{d. Hasil Uji F}

Uji F digunakan untuk menentukan signifikan antara variabel (X) yaitu nilai-nilai religiusitas terhadap variabel (Y) yaitu hasil belajar siswa dalam pembelajaran pendidikan Agama Islam kelas IV dan V di SDN 10 Lubuk Alung. Berikut ini hasil uji F yang dihasilkan pada model regresi dalam penelitian ini:

\section{Tabel 8. Hasil Uji F (Simultan)}

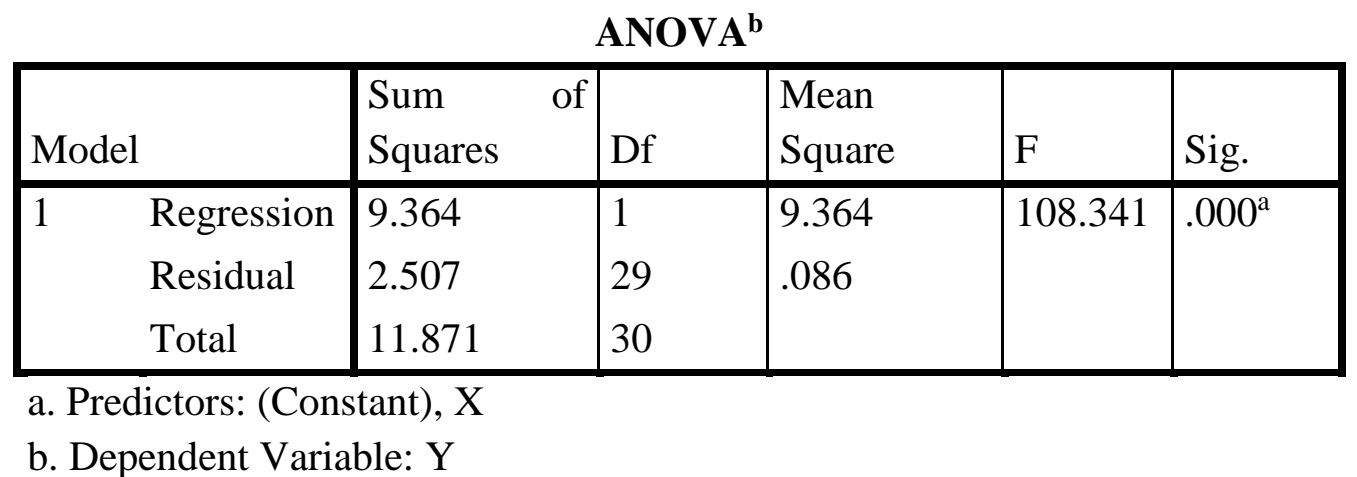

Uji $\mathrm{F}$ pada tabel di atas dapat diketahui bahwa Fhitung 108,341>4,16 dan nilai signya sebesar 0,000 yang mana $0,000<0,05$, sehingga $\mathrm{H} 0$ ditolak dan Ha diterima yang berarti variabel independen yakni nilai-nilai religiusitas berpengaruh signifikan terhadap variabel dependen yakni hasil belajar siswa dalam pembelajaran pendidikan Agama Islam kelas IV dan V di SDN 10 Lubuk Alung. Jadi dapat disimpulkan bahwa terdapat pengaruh antara nilainilai religiusitas terhadap hasil belajar siswa dalam pembelajaran pendidikan Agama Islam kelas IV dan V di SDN 10 Lubuk Alung.

Berdasarkan data nilai-nilai religiusitas kelas IV dan V di SDN 10 Lubuk Alung perolehan data dari penyebaran angket dapat dikategorikan yaitu; tinggi, sedang, rendah. Dari keseluruhan sampel yang berjumlah 31 orang siswa, jumlah siswa yang paling banyak terdapat pada kategori cukup baik/sedang sebanyak 22 siswa dengan persentase 71,0\%, dilanjutkan dengan kategori sangat baik/tinggi sebanyak 4 siswa dengan persentase 12,9\%, kemudian kategori kurang baik/rendah sebanyak 5 siswa dengan persentase 16,1\%. Maka dapat disimpulkan bahwa sebagian besar nilai-nilai religiusitas siswa kelas IV dan V SDN 10 Lubuk Alung berada pada kategori cukup baik/sedang.

Berdasarkan hasil analisis data hasil belajar siswa dalam pembelajaran Pendidikan Agama Islam kelas IV dan V di SDN 10 Lubuk Alung dapat dikategorikan yaitu tinggi, sedang dan rendah. Jumlah seluruh sampel 31 siswa, jumlah siswa yang paling banyak berada dalam kategori sedang sebanyak 19 siswa dengan persentase 61.3\%, dilanjutkan dengan kategori tinggi sebanyak 5 siswa dengan persentase $16.1 \%$, kemudian kategori rendah sebanyak 7 siswa dengan persentase 22.6\%. maka dapat disimpulkan bahwa sebagian besar hasil belajar siswa dalam pembelajaran Pendidikan Agama Islam kelas IV dan V di SDN 10 Lubuk Alung berada pada kategori sedang. 
Bagian ini akan membahas analisis hasil penelitian yang telah dilakukan mengenai pengaruh nilai-nilai religiusitas terhadap hasil belajar siswa dalam pembelajaran Pendidikan Agama Islam kelas IV dan V di SDN 10 lubuk Alung. Untuk mengetahui pengaruh kedua variabel tersebut penulis menggunakan batuan program analisis data SPSS versi 26. Hasil penelitian menunjukkan bahwa ada pengaruh yang signifikan antara nilai-nilai religiusitas terhadap hasil belajar siswa dalam pembelajaran Pendidikan Agama Islam kelas IV dan V di SDN 10 lubuk Alung. Hal ini dibuktikan pada uji $\mathrm{T}$ (parsial) yang diperoleh nilai t-hitung sebesar 10,409>1,695 dan nilai sig dari nilai-nilai religiusitas sebesar 0,000 yang mana $0,000<0,05$, sehingga H0 ditolak dan Ha diterima, artinya nilai-nilai religiusitas secara parsial berpengaruh positif dan signifikan terhadap hasil belajar siswa dalam pembelajaran pendidikan Agama Islam kelas IV dan V di SDN 10 Lubuk Alung. Melalui hasil uji analisis regresi linear sederhana menunjukkan bahwa terdapat pengaruh antara nilai-nilai religiusitas terhadap hasil belajar siswa dalam pembelajaran Pendidikan Agama Islam, mendapatkan nilai persamaaan regresi linear sederhana yaitu; $\mathrm{Y}=-2,353+0,061 \mathrm{X}$ dengan sig $0,000<0,05$. Dari persamaan diatas dapat diartikan bahwa setiap penambahan $1 \%$ nilai-nilai religiusitas (X) akan meningkatkan hasil belajar siswa dalam pembelajaran pendidikan Agama Islam kelas IV dan V di SDN 10 Lubuk Alung sebesar 0,061\%. Melalui uji koefisien determinasi (R2) diketahui R sebesar 0,888 dan nilai $\mathrm{R}$ Square sebesar 0,789. Hal ini mengandung arti bahwa persentase yang menyumbangkan pengaruh nilai-nilai religiusitas (X) terhadap hasil belajar siswa dalam pembelajaran pendidikan Agama Islam (Y) secara simultan adalah 78,9\%, sedangkan 21,1\% dipengaruhi oleh faktor lain yang mempengaruhi hasil belajar seperti kecerdasan, bakat, sikap, kebisaan, motivasi, perilaku, kebutuhan, minat, emosi, lingkungan dan lain sebagainya.

Kemudian berdasarkan uji F (simultan) dapat dilihat bahwa F-hitung 108,341>4,16 dan nilai sig. 0,000 yang mana $0,000<0,05$, sehingga $\mathrm{H} 0$ ditolak dan Ha diterima yang berarti variabel independen $(\mathrm{X})$ yakni nilai-nilai religiusitas berpengaruh signifikan terhadap variabel dependen (Y) yakni hasil belajar siswa dalam pembelajaran pendidikan Agama Islam. Nilai-nilai religusitas mempunyai kedudukan yang sangat penting dalam kehidupan manusia baik sebagai individu maupun sebagai masyarakat, bahkan dalam Pendidikan Agama Islam dianjurkan dan diajarkan untuk memiliki nilai-nilai religiusitas yang baik serta diharapkan dapat dilaksanakan dan dibiasakan dalam kehidupan sehari-hari terkhususnya pada siswa kelas IV dan V di SDN 10 Lubuk Alung. Hal ini sesuai dengan yang dikemukakan Wati dan Arif (2017) Nilai religius merupakan salah satu nilai karakter yang dijadikan sebagai sikap dan perilaku yang patuh dalam melaksanakan ajaran agama yang dianut, toleran terhadap pelaksanaan ibadah agama lain, dan hidup rukun dengan pemeluk agama lain. Karakter religius perlu di ajarkan sejak anak usia dini, beberapa karakter religius yang harus ditanakam kepada anak yaitu nilai norma dan moral seperti jujur, disiplin, mandiri, kerja keras, kreatif, hormat kepada orang lain, tanggung jawab, cinta tanah air, kepepimpinan dan keadilan. Salah satu tempat untuk menanamkan karakter religius pada anak adalah sekolah.

Kemudian Uno (2008) menambahkan bahwa karakteristik siswa merupakan salah satu hal yang perlu diidentifikasi oleh guru untuk digunakan sebagai petunjuk dalam upaya mengoptimalkan proses pembelajaran. Diantaranya adalah religiusitas tinggi atau rendah yang memiliki kontribusi besar dalam pembentukan karakter dan hasil belajar siswa dalam 
mengimplementasikan nilai-nilai keIslaman dalam kehidupan sehari-hari. Hasil belajar adalah kemampuan yang diperoleh anak setelah melalui kegiatan belajar. Belajar adalah suatu aktivitas yang dilakukan seseorang dengan sengaja dalam keadaan sadar untuk memperoleh suatu konsep, pemahaman, atau pengetahuan baru sehingga memungkinkan terjadinya perubahan perilaku yang relatif tetap baik dalam berpikir, merasa, maupun dalam bertindak. Sedangkan pembelajaran merupakan bantuan yang diberikan guru agar terjadi proses pemerolehan ilmu dan pengetahuan, penguasaan, kemahiran dan tabiat, serta pembentukan sikap dan keyakinan pada siswa. Dari data hasil penelitian yang diperoleh, dapat disimpulkan bahwa semakin tinggi nilainilai religiustitas siswa maka semakin tinggi pula hasil belajar siswa dalam pembelajaran pendidikan Agama Islam yang diperolehnya. Siswa yang medapatkan didikan dari orang tua dengan baik, memiliki lingkungan dan pergaulan yang baik, teladan, penuh kasih sayang, pengawasan, perhatian serta disiplin, akan mempengaruhi dirinya untuk mendapatkan hasil belajar yang baik pula. Sedangkan siswa yang memiliki masalah dalam hidup dan lingkungannya serta memiliki perbuatan yang kurang baik, cenderung memiliki hasil belajar Pendidikan Agama Islam yang rendah.

Meskipun begitu, hasil belajar siswa bukan semata-mata hanya dipengaruhi oleh nilainilai religiusitas tapi juga dapat dipengaruhi oleh kecerdasan, bakat, sikap, kebisaaan, motivasi, perilaku, kebutuhan, minat, emosi, lingkungan dan lain sebagainya. Akan tetapi, nilai-nilai religiusitas yang baik dapat diperoleh dengan pembentukan, penanaman pembisaaan, dan pengawasan yang baik mulai sejak usia dini. Pembentukan dan penanaman pembisaaan nilainilai religiusitas dapat dilihat pada kepribadian Rasulullah SAW, para sahabat, tabi'in dan para ulama yang patut dijadikan contoh nyata dalam hidup. Sehingga kita dapat menerapkan hal tersebut dalam kehidupan sehari-hari.

\section{KESIMPULAN}

Berdasarkan data yang diperoleh dari hasil analisis yang telah dilakukan maka dapat ditarik kesimpulan sebagai berikut: 1) Hasil penelitian dari nilai-nilai religiusitas kelas IV dan V di SDN 10 Lubuk Alung tahun ajaran 2021/2022 berada pada kategori cukup baik/sedang. Hal ini dibuktikan dari perhitungan interval 61-68 sebanyak 22 siswa dengan persentase 71,0\%. 2) Hasil analisis dari nilai hasil belajar siswa kelas IV dan V di SDN 10 Lubuk Alung tahun ajaran 2021/2022 berada pada kategori sedang. Hal ini dibuktikan dari perhitungan interval 62-74 sebanyak 19 siswa dengan persentase 61,3\%. 3) Berdasarkan perhitungan menggunakn uji T (parsial) diperoleh nilai thitung sebesar 10,409>1,695 dan nilai sig dari nilai-nilai religiusitas sebesar 0,000 yang mana 0,000<0,05, sehingga H0 ditolak dan Ha diterima, berarti nilai-nilai religiusitas secara parsial berpengaruh positif dan signifikan terhadap hasil belajar siswa. Melalui hasil perhitungan nilai persamaaan regresi linear sederhana yaitu; $\mathrm{Y}=-2,353+0,061 \mathrm{X}$, sig. $0,000<0,05$, maka kesimpulannya terdapat pengaruh antara nilai-nilai religiusitas terhadap hasil belajar siswa. Berdasarkan output yang diperoleh uji koefisien determinasi (R2) diketahui R sebesar 0,888 dan nilai R Square sebesar 0,789 atau 78,9\%, maka dapat disimpulkan bahwa nilai-nilai religiusitas memiliki pengaruh yang signifikan terhadap hasil belajar. Kemudian berdasarkan uji F (simultan) dapat dilihat bahwa Fhitung 108,341>4,16, dan sig. sebesar 0,000 yang mana $0,000<0,05$, sehingga $\mathrm{H} 0$ ditolak dan Ha diterima, berarti nilai-nilai religiusitas 
berpengaruh signifikan terhadap hasil belajar siswa. Hal ini menunjukkan bahwa semakin tinggi nilai-nilai religiustitas siswa maka semakin tinggi pula hasil belajar siswa dalam pembelajaran pendidikan Agama Islam.

\section{DAFTAR PUSTAKA}

Ahmad, Susanto. (2013). Teori Belajar dan Pembelajaran di Sekolah Dasar. Jakarta: Kencana.

Agus, Suprijono. (2010). Cooperative Learning Teori dan Aplikasi PAIKEM. Yogyakarta: Pustaka Pelajar.

Alfadhil, M. (2019). Internalisasi Nilai Religiusitas pada Anak Dalam Keluarga. Jurnal MUDARRISUNA: Media Kajian Pendidikan Agama Islam, 9(1), 26-35.

Aviyah, Evi, \& Farid. M. (2014). Religiusitas, kontrol diri dan kenakalan remaja. Persona: Jurnal Psikologi Indonesia 3.02, 127.

Daradjat, Zakiah. (2014). Ilmu Pendidikan Islam. Jakarta : Bumi Aksara.

Fatmawati, L. (2018). Pengaruh hasil belajar PAI terhadap akhlak siswa kelas VIII SMP Negeri 13 Malang (Doctoral dissertation, Universitas Islam Negeri Maulana Malik Ibrahim).

Fathurrohman, Muhammad. (2015). Budaya Religius dalam Meningkatkan Mutu Pendidikan: Tinjauan Teoritik dan Praktik Kontekstualisasi Pendidikan Agama di Sekolah. Yogyakarta: Kalimedia.

Hawi, Akmal. (2014). Kompetensi Guru Pendidikan Agama Islam. Jakarta: rajawali pers.

Hidayati, S. (2016). Pengaruh Strategi Pembelajaran Dan Religiusitas Terhadap Hasil Belajar Pendidikan Agama Islam Siswa Kelas XI SMK Telkom Sandhy Putra Medan Tahun Ajaran 2009/2010. Tadrib, 2(1), 123-150.

Khaeriyah, U. (2019). Pengaruh religiusitas orang tua terhadap prestasi belajar pendidikan agama islam siswa kelas VII SMP Negeri 1 Kajen (Doctoral dissertation, IAIN Pekalongan).

Khoerunnisa, K. (2017). Pengaruh pengetahuan tentang keberagamaan terhadap hasil belajar PAI siswa kelas V di SDN 02 Pesucen Kecamatan Petarukan Kabupaten Pemalang (Doctoral dissertation, UIN Walisongo).

Kountur, Ronny. (2003). Metode Penelitian. Jakarta:PPM

Muliawan, Jasa Ungguh. (2005). Pendidikan Islam Integratif. Yogyakarta: Pustaka Pelajar.

Najib, M. A. (2018). Konsep Dan Implementasi Pembinaan Religiusitas Siswa Di SMA. Jurnal Tawadhu, 2(2), 556-571.

Nasution, M. K. (2018). Penggunaan metode pembelajaran dalam peningkatan hasil belajar siswa. Studia Didaktika,11(01), 9-16.

Sjarkawi. (2008). Pembentukan Kepribadian Anak. Jakarta: Bumi Aksara

Saputra, H. D., Ismet, F., \& Andrizal, A. (2018). Pengaruh motivasi terhadap hasil belajar siswa SMK. Invotek: Jurnal Inovasi Vokasional dan Teknologi, 18(1), 25-30

Sudjana, Nana. (2011). Penilaian Hasil Proses Belajar Mengajar. Bandung: Remaja Rosdakarya. 
Sugiyono. (2010). Metode Penelitian Pendidikan (Pendekatan Kualitatif, Kuantitatif, dan R\&D. Bandung: Alfabeta.

Sugiyono. (2012). Metode Penelitian Kuantitatif, Kualitatif, dan R\&D. Bandung: Alfabeta

Sumantri, Mohammad. Syarif. (2016). Strategi Pembelajaran Teori dan Praktik di Tingkat Pendidikan Dasar. Jakarta:Rajawali Pers.

Syarnubi, S. (2019). Profesionalisme Guru Pendidikan Agama Islam dalam Membentuk Religiusitas Siswa Kelas IV di SDN 2 Pengarayan. Tadrib, 5(1), 87-103.

Umar, M \& Ismail, F. (2020). Buku ajar pendidikan agama Islam: konsep dasar bagi mahasiswa perguruan tinggi umum. Penerbit Cv. Pena Persada.

Umro, J. (2018). Penanaman Nilai-Nilai Religius di Sekolah yang Berbasis Multikultural. Jurnal Al-Makrifat Vol, 3(2).

Uno, H. (2008). Orientasi Baru dalam Psikologi Pembelajaran. Jakarta: Bumi Aksara.

UU RI No.20 tahun 2003 Bab II pasal 3 tentang SISDIKNAS, Bandung: Fokus Media.

Wati, D. C., \& Arif, D. B. (2017). Penanaman nilai-nilai religius di sekolah dasar untuk penguatan jiwa profetik siswa 